\title{
Deformation Mechanism and Support Technology of Deep and High-Stress Soft Rock Roadway
}

\author{
Lujing Zheng $\mathbb{D D}^{1,2}$ Yujun Zuo $\mathbb{D}^{1},{ }^{1}$ Yafei Hu $\mathbb{D D}^{3}$ and Wei Wu $\mathbb{D}^{2}$ \\ ${ }^{1}$ Mining College, Guizhou University, Guiyang, Guizhou 550025, China \\ ${ }^{2}$ Sino Guizhou Jinfeng Mining Limited, Southwest of Guizhou, Guiyang, Guizhou 562204, China \\ ${ }^{3}$ School of Civil and Resource Engineering, University of Science and Technology Beijing, Beijing 100083, China \\ Correspondence should be addressed to Yujun Zuo; cailyouxiang@163.com
}

Received 9 December 2020; Revised 11 January 2021; Accepted 2 March 2021; Published 23 March 2021

Academic Editor: Andreas Lampropoulos

Copyright $\odot 2021$ Lujing Zheng et al. This is an open access article distributed under the Creative Commons Attribution License, which permits unrestricted use, distribution, and reproduction in any medium, provided the original work is properly cited.

In this study, the analysis and control of stability of surrounding rock in deep fractured soft rock roadway located in the underground mine of Jinfeng gold mine in Guizhou Province, China, has been investigated. The surrounding rock of roadway has been analyzed to characterize its deformation and failure mechanism through field survey, testing of rock physical and mechanical properties, in situ stress measure, analysis of mineral components of rock, and investigation of rock fragmentation degree. Based on the numerical simulation technology, the influence of different factors on the stability of roadway is studied. The physical and mechanical properties of surrounding rock and the bearing capacity of surrounding rock layer are to be improved to maintain the stability of broken soft rock roadway as high ground stress, rock fragmentation, and poor lithology leading to tunnel instability. Hence, a high-strength "cable bolt + fiber-reinforced shotcrete + steel mesh + split sets + resin bolt + cement grouting" combined support system has been proposed to improve the effective bearing structure significantly with high integrity and bearing capacity.

\section{Introduction}

At present, the main mining countries have entered into the deep mining stage and initiated for developing deep roadway support which normally faces challenges in deep mining $[1,2]$. It is difficult to ensure the stability of the deep broken soft rock roadway due to several influencing factors such as mining activities, rock mass physical and mechanical properties, and high-stress field, which directly cause difficulties in finding the stability control of surrounding rock [3-11]. The abundant scientific research achievements have been done by many researchers around the world to solve the ground support problem of deep soft surrounding rock roadway through developing new technology for deep soft rock roadway surrounding rock control, new theory, and performing the industrial test. He Manchao [12] studied deep roadway supports through test method and equipment of deep soft rock engineering with characteristics such as water absorption and softening mechanism of deep soft rock, asymmetric large deformation mechanism of soft rock, and explosion mechanism of deep soft rock. Zhang Guangchao et al. [13] investigated the stability control of surrounding rock in the deep fractured soft rock roadway by proposing a combined support system developed based on the high-strength bolt-intensive support, the new type of shotcrete structure protection, and the cement grouting reinforcement to characterize the deformation and failure characteristics and failure mechanism of the surrounding rock. Wang Weijun et al. [14] investigated the behavior of controlling large deformation of surrounding rock of deep high-stress roadway based Kastner and other relevant theories to study the influence of support resistance and revealed that controlling the mechanical nature of its deformation is difficult. Finally, a new support concept of surrounding rock stability control of roadway was proposed and proved as an efficient system.

Prediction of a complex geological structure is still changeable, though the findings of qualitative research of the ground support theory of deep soft rock roadway are available due to the rock mass buried in the deep. It can be 
concluded that most of the underground engineering faces challenges in different support problems [15-17]. Xie Heping confirms that the true characteristics of the typical "Three High" occurrence environment and the additional attribute of "strong disturbance" and "strong aging" of resource exploitation of deep rock mass lead to frequent engineering disasters of high energy level and large volume in deep rock mass because of the applicability of traditional rock mechanics and mining theory in deep rock mass offers unclear mechanism, which is difficult to predict and control [18]. It can be concluded from the literature that the development of an efficient constructive ground support system for support in deep fractured soft rock roadway still has the scope for research interest.

In this study, the analysis and control of the stability of surrounding rock in deep fractured soft rock roadway located in the $90 \mathrm{~m}$ underground mine of Jinfeng gold mine in Guizhou Province, China, are investigated. The surrounding rock of roadway is analyzed to characterize its deformation and failure mechanism through field survey, testing of rock physical and mechanical properties, in situ stress measure, analysis of mineral components of rock, and investigation of rock fragmentation degree. The damage of the tunnel is tested by field investigation test methods, laboratory mechanical tests, theoretical analysis, and numerical simulation. As the literature concludes that the physical and mechanical properties of surrounding rock and the bearing capacity of surrounding rock layer are to be improved to maintain the stability of broken soft rock roadway as high ground stress, rock fragmentation degree, and lithology (rock strength) leading to tunnel instability, combined support system with a high-strength "cable bolt + fiberreinforced shotcrete + steel mesh + split sets + resin bolt + cement grouting" is proposed and field engineering tests are carried out to solve the stability problem of surrounding rock in the deep broken weak roadway to improve the effective bearing structure significantly with high integrity and bearing capacity.

\subsection{Engineering Background. A typical structural ore con-} trolling deposit of Guizhou Jinfeng gold mine is located in Shaping Township, Zhenfeng County, Southwest of Guizhou Province, China. The strike of the ore body has geometrical space within the length, width, and vertical depth about $1000 \mathrm{~m}, 5-40 \mathrm{~m}$, and more than $1000 \mathrm{~m}$, respectively, and the underground portal elevation is $560 \mathrm{~m}$. The multistage geological structure of the mining area with a schematic illustration of influences of the various constituents is presented in Figure 1 and results in rock mass fracture and joint development in the mining area when it fails to control. The Jinfeng mining area is bounded by the Permian Triassic boundary (or F1) and can be divided into eastern and western structural areas. The structure of the western structural area is simple, and it is monoclinic strata, which inclines to the northeast and gradually changes to the southeast from the south. The dip angle is gentle, and the dip angle is between $10^{\circ}$ and $28^{\circ}$. The structure of the eastern

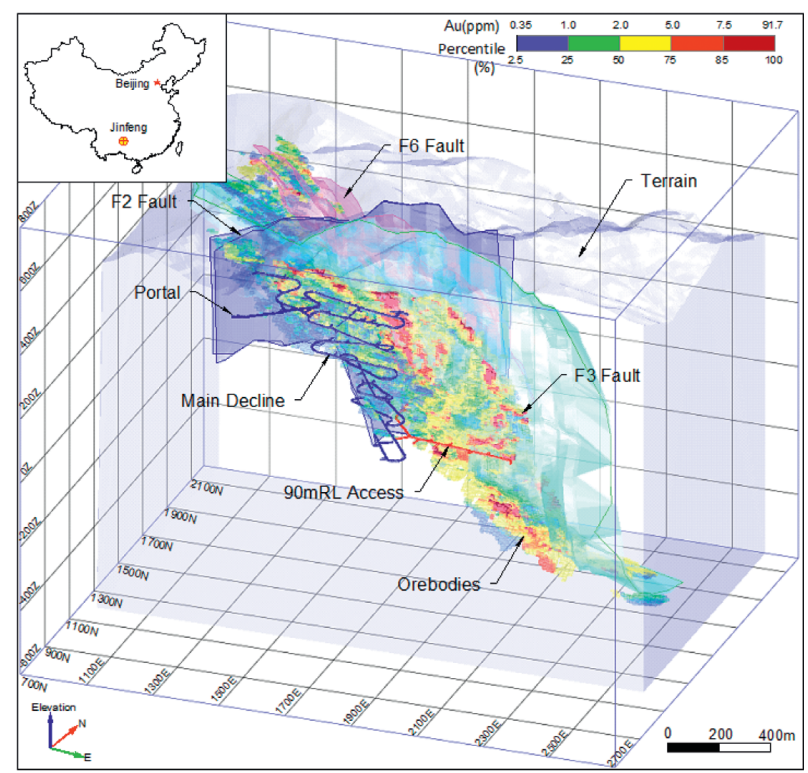

Figure 1: The location of Jinfeng gold mine and the main structures.

structural area is complex, mainly including $\mathrm{NW}, \mathrm{SN}$, and NE fold and fault combination.

Jinfeng underground gold mine in Guizhou has been cut and filled as developed by ramp and the mining method. The deep rock body is mainly constituted of sandstone, sandy mudstone, and mudstone. The development of joint fissures of the rock mass causes the breaking of the rock mass due to the geological structures. At present, Guizhou's Jinfeng underground gold mine is at a $90 \mathrm{~m}$ level in the development stage. The profile of the roadway is designed with a width and a height of $5 \mathrm{~m}$ and $5.5 \mathrm{~m}$, respectively, as a straight wall triple arch. The original ground support design is considered with support schemes such as bolting, meshing, and shotcreting as presented in Figure 2. The parameters of ground support considered 5 resin bolts with $\varphi 25 \mathrm{~mm} @ 2400 \mathrm{~mm}$ in each row of the roof, the row spacing between resin bolts with $1200 \mathrm{~mm}$ by $1500 \mathrm{~mm}$, the drilling diameter with $\varphi 35 \mathrm{~mm}, 3$ split sets with $\varphi 47.5 \mathrm{~mm} @ 2400 \mathrm{~mm}$ in each row of two sides, and the row spacing between them with $1200 \mathrm{~mm}$ by $1200 \mathrm{~mm}$. The thickness of C30 concrete shotcrete considered is $100 \mathrm{~mm}$. Generally, it was observed that the deep fractured soft rock roadway with the above considered supporting method experiences deformation of the roadway and shotcrete cracking on the sidewall and floor heaving after two months of installation, finally leading to failure of the support elements followed by the tunnels. It was noticed that great variations are found in deformation and failure type between waste rock and ore excavation openings due to the developed differences in lithology, rock mass fractured, and tectonic stress. It can be concluded from the observation that it is difficult to support with current support method. So, the development of an efficient constructive ground support system for support in deep soft rock roadway in Guizhou's Jinfeng underground gold mine is significant. 


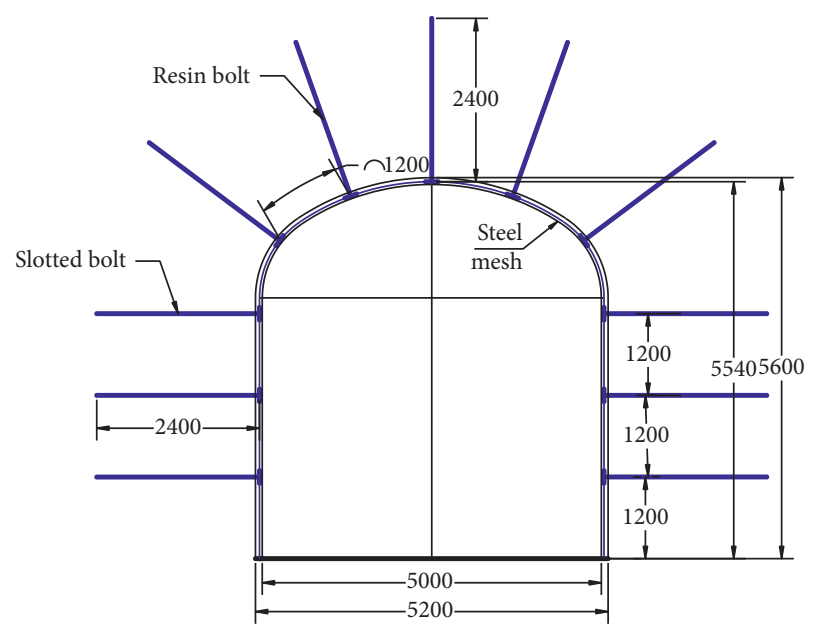

Figure 2: Original support scheme of deep roadway.

\subsection{Analysis of Deformation Characteristics and Influencing} Factors of Surrounding Rock in the Deep Roadway. The analysis of surrounding rock in deep fractured soft rock roadway located in the underground mine of Jinfeng gold mine in Guizhou Province, China, has been investigated and a large area of deformation and destruction observed in the surrounding rock of deep broken weak roadway because of the compression of near-horizontal structural stress developed was noticed, as presented in Figure 3. Few effects through the field investigation of the deformed roadway were also noticed, such as large displacement of the two sides of the roadway, serious spalling and cracking at the shotcreting layer of the side, and falling rock mass from the back locally. Further, few other effects were observed, such as many cracks at the arch roof and the local floor bulging with more than $500 \mathrm{~mm}$ and partial or complete destruction of anchor bolt due to the stress developed at the steel showing distortion and deformation of reinforcement net and concrete layer sprayed to surrounding rock of roadway. follows:

The main factors affecting roadway deformation are as

(1) Ground support strength: generally, the different ways of support can provide different supporting strength. At present system, the main ground support considered in the mine is the long cable bolt + shotcrete + mesh + resin bolt + split sets in which the long cable bolt, resin bolt, split sets, shotcreting, and meshing are kept for roadway crossing support, roadway roof, the sidewall, and strengthening the surface strength of surrounding rock mass of roadway. It can be concluded that the support is with high grade and its stability is good if the deformation of the roadway is small.

(2) Rock mass properties: the surrounding rock of Jinfeng gold mine is mainly constituted of sandstone, sandy mudstone, mudstone, and their interbeds. As it is known, the different strengths of surrounding rock available provide different self-bearing forces. Generally, the development roadway is mainly located in sandstone, argillaceous sandstone, and other lithologies in the same horizontal roadway. It can be understood that weak lithology such as mudstone and sandy mudstone yields smaller deformation amount and deformation rate of the roadway compared to the newly developed roadway.

(3) In situ stress: the in situ stress in the deep roadway is primarily structural stress and vertical stress. As it is known that the ground stress increases gradually with the increase of mining depth, it can be observed in the mine that the deformation and damage degree of deep roadway measures is far greater than shallow roadway considered for the same level of support strength and surrounding rock and appears with large-scale cracking, large deformation, floor heave, and shotcrete and rock mass falling off below $150 \mathrm{~m}$ level in underground.

(4) Fractured rock mass: the ore body was mainly enriched within F2, F3, and F6 faults zone and experienced the faults due to multiple tectonic activities which result in the fracture of rock mass in the fault zone. It can be understood that a large number of fault breccia and the development of joint fissures and the extremely broken surrounding rock in the ore body occur in the fault zone. It was observed through investigation that the integrity of rock mass is far better than the fault zone but the structural stress increases obviously here which creates a great impact on the stability of the roadway.

\section{Parameters Test}

The experiments/tests were conducted on the four main factors considered affecting roadway deformation to analyze quantitatively the factors influencing the roadway deformation.

2.1. Physical and Mechanical Test of the Surrounding Rock. Generally, the stability of the deep roadway and the design of support parameters are influenced by the physical and mechanical properties of surrounding rocks $[19,20]$. Therefore, tests are carried out on borehole coring of the underground surrounding rock to characterize the physical and mechanical properties and the test results obtained are presented in Table 1.

It was observed from Table 1 that the strength of sandstone and argillaceous sandstone among the four types of roadway surrounding rocks is relatively high with the uniaxial compressive strength (UCS) being $42.1 \mathrm{MPa}$ and $36.7 \mathrm{MPa}$, respectively, while the strengths of sandy mudstone and mudstone of the main surrounding rocks of deep roadway are relatively lower than ultimate compressive strength being only $29.5 \mathrm{MPa}$ and $21.2 \mathrm{MPa}$, respectively. Due to the poor lithology of deep surrounding rock, the bearing capacity of surrounding rock is insufficient after excavation, which leads to roadway instability.

2.2. In Situ Stress Measurement. It was known that the magnitude and direction of in situ stress have a great relationship with the stability of the surrounding rock. So, it 


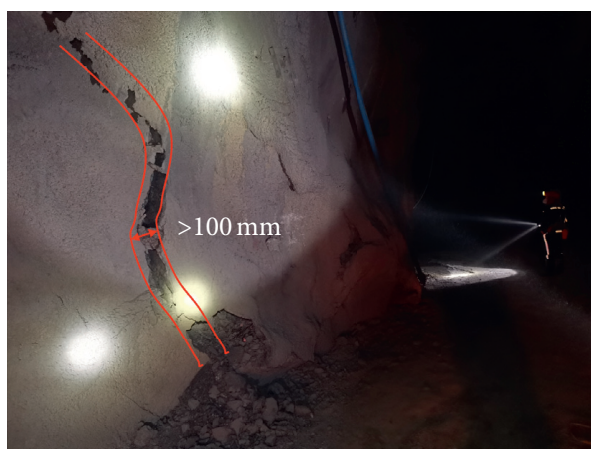

(a)

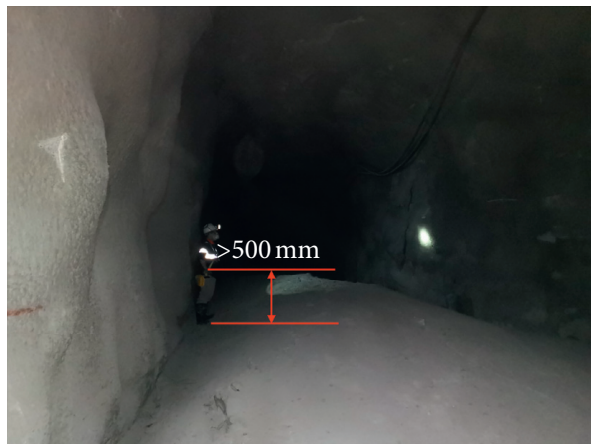

(c)

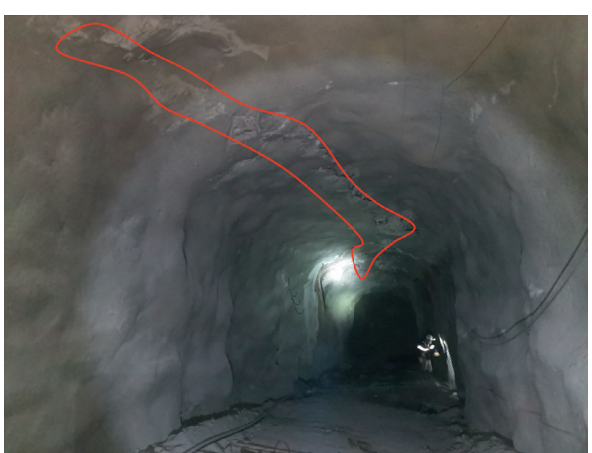

(b)

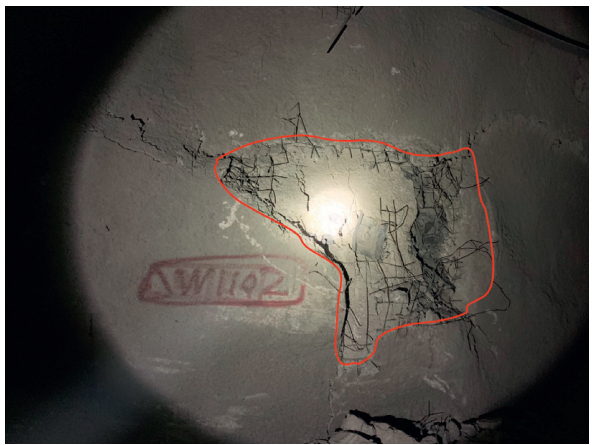

(d)

Figure 3: Deformation situations in $90 \mathrm{mRL}$ access. (a) Deformation and crack on the wall. (b) Roof break. (c) Floor heave. (d) Concrete layer falling off.

TABLE 1: The physical and mechanical properties of rocks.

\begin{tabular}{lcccccc}
\hline Lithology & $\begin{array}{c}\text { UCS } \\
(\mathrm{MPa})\end{array}$ & $\begin{array}{c}\text { Strength of extension } \\
(\mathrm{MPa})\end{array}$ & $\begin{array}{c}\text { Cohesion } \\
(\mathrm{MPa})\end{array}$ & $\begin{array}{c}\text { Internal friction angle } \\
\text { (degree) }\end{array}$ & $\begin{array}{c}\text { Elasticity modulus } \\
(\mathrm{MPa})\end{array}$ & $\begin{array}{c}\text { Poisson's } \\
\text { ratio }\end{array}$ \\
\hline Sandstone & 42.1 & 3.2 & 2.8 & 35.5 & 23000 & 0.29 \\
Argillaceous & 36.7 & 2.8 & 2.1 & 31 & 27.5 & 18000 \\
sandstone & 29.5 & 2.2 & 1.6 & 20 & 8500 & 0.26 \\
Sandy mudstone & 21.2 & 1.0 & 0.6 & 0.23 \\
Mudstone & & & & & & 6500 \\
\hline
\end{tabular}

can be understood that the precondition for the stability analysis of surrounding rock depends on the measurement of in situ stress, which can guide the realization of scientific and reasonable tunnel design [21, 22]. The hollow inclusion gauge stress relief method was adopted in the field to carry out the in situ stress test at the level of $90 \mathrm{~m}$ main access which is $600 \mathrm{~m}$ below the surface, while the DCDA method was adopted to carry out sampling test in laboratory for the other elevation cores.

It can be observed from the test results of stress relief method of hollow inclusion gauge that the maximum and the minimum horizontal principal stresses of $90 \mathrm{~m}$ main access are $21.1 \mathrm{MPa}$ and $13.5 \mathrm{MPa}$, respectively, the vertical principal stress is $16.2 \mathrm{MPa}$, and the average lateral pressure coefficient is 1.1 as presented in Table 2. It was noticed that the tunnel has a high state of stress when its buried depth is more than $600 \mathrm{~m}$. It was also observed through the field investigation that the arch crown provides clear horizontal extrusion deformation and the shotcrete cracks and falls off with a buried depth of more than $600 \mathrm{~m}$. Further, it was observed that the two sides of the shotcrete move towards the center of the roadway due to characteristics of shear failure and the floor of the roadway yields the phenomenon of floor heave and cracking, which is an important manifestation of the extrusion, crushing, and creep of the surrounding rock of the roadway under the action of high stress.

2.3. Analysis of Surrounding Rock Composition. The composition of underground ore and rock minerals have been determined using D/max-2200 X-ray diffractometer in the experiment with core sampling analysis of typical borehole sections and the results of the analysis are presented in Tables 3 and 4 . By X-ray diffraction analysis, it was noticed that rock mass contains quartz, plagioclase, calcite, dolomite, iron pyrite, and clay minerals content. It was also noticed that the percentage of constituents of the rock mass is quartz 
TABLE 2: The measurement results of in situ stress.

\begin{tabular}{lccccc}
\hline Depth below surface $(\mathrm{m})$ & $\sigma_{1}(\mathrm{MPa})$ & Dip angle (degree) & $\sigma_{3}(\mathrm{MPa})$ & Dip angle $($ degree $)$ & $\sigma_{\mathrm{z}}(\mathrm{MPa})$ \\
\hline 400 & 8.6 & 9 & 6.5 & 13.5 & 8 \\
600 & 21.1 & 10 & 14.8 & 9.8 & 16.2 \\
800 & 32 & 10 & 15.44 & 9 & 21.6 \\
1000 & 45 & 10 & & 9 \\
\hline
\end{tabular}

TABLE 3: X-ray diffraction analysis of all rock minerals.

\begin{tabular}{lcccccccc}
\hline Sample & $\mathrm{Au}(\mathrm{g} / \mathrm{t})$ & Quartz (\%) & Anorthose (\%) & Calcite (\%) & Ankerite (\%) & Siderite (\%) & Pyrite (\%) & Clay minerals (\%) \\
\hline S03-1\# & 0.00 & 53.60 & 12.80 & 15.00 & 7.70 & 1.50 & - & 9.50 \\
S03-2\# & 0.00 & 40.50 & 2.30 & 2.60 & 25.50 & 0.70 & - & 0.80 \\
S03-3\# & 0.01 & 70.90 & 0.60 & 7.30 & 11.10 & - & 1.30 & 9.20 \\
S03-4\# & 12.05 & 83.40 & 0.40 & 2.20 & 4.70 & - & 1.40 & 8.00 \\
S03-5\# & 10.90 & 89.20 & - & 0.40 & 2.50 & - & 6.50 \\
S03-6\# & 3.50 & 84.50 & 0.40 & 0.90 & 6.00 & - & 1.30 & 6.90 \\
S03-7\# & 7.69 & 86.30 & 0.40 & - & 3.30 & - & 1.80 & 8.20 \\
\hline
\end{tabular}

TABLE 4: X-ray diffraction analysis of clay minerals.

\begin{tabular}{|c|c|c|c|c|c|c|}
\hline Sample & $S$ & $\mathrm{I}$ & $\mathrm{K}$ & $\mathrm{C}$ & $\mathrm{I} / \mathrm{S}$ & $\mathrm{C} / \mathrm{S}$ \\
\hline S03-1\# & & 58 & 11 & 20 & 11 & \\
\hline S03-2\# & & 83 & 4 & 10 & 3 & \\
\hline S03-3\# & & 72 & & & 28 & \\
\hline S03-4\# & & 54 & 12 & 21 & 13 & \\
\hline S03-5\# & & 74 & 9 & & 17 & \\
\hline S03-6\# & & 76 & & & 24 & \\
\hline S03-7\# & & 79 & & & 21 & \\
\hline
\end{tabular}

S: smectite; I: illite; K: kaolinite; C: chlorite; I/S: illite/smectite formation; C/ S: chlorite/smectite formation.

content with a higher range of $40.50 \%$ to $86.30 \%$ and an average of $72.63 \%$ and clay mineral content with a range of $6.5 \%$ to $28.40 \%$ and an average of $10.96 \%$. Further, it was observed from the analysis that illite is the main constituent of clay mineral composition with an average content of $70.85 \%$. It can be concluded that the groundwater penetrating the mining surface along the fault fracture zone affects the tunnel stability when exposed to water due to expansion and softening characteristics of clay minerals.

2.4. Investigation of Fractured Rock Mass. As it is known that the fracture degree of underground surrounding rock is affected by faults, folds, joint development, blasting excavation, and other factors, generally, the fracture degree of original rock can be described by the RQD value of the rock quality index. The impact of blasting excavation on the fracture of surrounding rock can be quantitatively analyzed through the measurement of the broken rock zone. A 3D visual model has been established using the three-dimensional software Surpac and extracted about total of 55390 the RQD value of Jinfeng geological database. All the results of the statistical analysis are presented in Table 5. It was observed that the RQD distribution obtained in the mining area is in the range of $0.025 \%-100 \%$, the average of the ore body is $36.93 \%$, and the average value in the surrounding rock is $37.66 \%$. It can be concluded that the rocks in the ore body are more broken than in the surrounding rock mass and the RQD values obtained from the 3D model are significant to guide the mining design and ground support design. Further, it was concluded through the field investigation that a direct impact on the stability of the surrounding rock is based on the parameters such as breaking of the surrounding rock, greater deformation of the roadway, and the degree of its breaking.

The acoustic wave testing technology is a new technology developed in recent decades to determine the rock broken zone of the surrounding rock. It can be understood that the physical and mechanical parameters and structural plane characteristics of the rock mass can be measured through studying the propagation characteristics of the acoustic wave in rock mass by considering acoustic waves as an information carrier. The results provided by acoustic wave testing are significant to guide ground support design $[23,24]$. In this study, RSM-SY5 intelligent acoustic instrument developed by Wuhan Institute of Geotechnical Mechanics of the Chinese Academy of Sciences has been adopted to detect and analyze the scope of surrounding rock loosening. It was observed through the field test that the rock broken zone is about $1.5 \mathrm{~m}$ and it was also observed that the rock mass is significantly varying at the rock broken zone, which affects the stability of the roadway. Therefore, effective ground support must be developed to ensure the stability of the roadway.

\section{Numerical Simulation of the Multifactor Coupling Effect}

The numerical simulation has been performed on the deformation and failure of roadway surrounding rock and the distribution characteristics of in situ stress under different tunnel buried depth to analyze the deformation and failure mechanism of roadway surrounding rock under the coupling action of multiple factors such as different in situ stress, lithology, support strength, and shotcreting thickness. Further, the main representative rocks sandstone, argillaceous sandstone, sandy mudstone, and mudstone are selected for quantitative simulation analysis. 
TABle 5: Statistics of RQD in different rock type.

\begin{tabular}{|c|c|c|c|c|c|c|c|c|}
\hline \multirow{2}{*}{ Rock type } & \multirow{2}{*}{$N$} & \multirow{2}{*}{ Min. } & \multicolumn{3}{|c|}{ Percentile (\%) } & \multirow{2}{*}{ Max. } & \multirow{2}{*}{ Mean } & \multirow{2}{*}{ Standard deviation } \\
\hline & & & 25 & 50 & 75 & & & \\
\hline Mineralization & 26,601 & 0.090 & 17.62 & 33.06 & 51.87 & 100.00 & 36.93 & 24.08 \\
\hline Waste rock & 28,789 & 0.025 & 20.00 & 35.70 & 53.00 & 100.00 & 37.66 & 21.85 \\
\hline All rocks & 55390 & 0.025 & 18.8 & 34.4 & 52.5 & 100.00 & 37.31 & 22.94 \\
\hline
\end{tabular}

3.1. Simulation Scheme Design. The simulation scheme design and modeling software chosen for the analysis are the orthogonal design and the rock mechanics software phase 2.0, respectively. The orthogonal experimental scheme design includes the main types of surrounding rock, in situ stress under different burial depth, different support strength, and shotcrete thickness as variables. The numerical model is shown in Figure 4.

The simulation scheme arrangement according to standard L16 $\left(4^{4}\right)$ table is presented in Table 6. The typical section has been selected for modeling by considering the roadway as three center $5.0 \mathrm{~m}$ wide and $5.5 \mathrm{~m}$ high arches. The Mohr-Coulomb criterion has been chosen for rock failure criterion and the model is $45 \mathrm{~m}$ wide and $50 \mathrm{~m}$ high.

3.2. Simulation Results and Analysis. The influence of various factors on the stability of the roadway can be justified, deformation of two sides and floor heave in 16 schemes of simulation test results by taking mudstone as an example, and is presented in Figures 5-8. It can be observed from the results of the analysis of the deformation characteristics of the mudstone roadway that the deformation of the roadway is the largest when the roadway buried depth, the bolt support strength, the shotcrete thickness, the floor heave, the roof subsidence, the displacement of the left side, and the displacement of the right side considered are $1000 \mathrm{~m}$, $200 \mathrm{kN}, 50 \mathrm{~mm}, 570 \mathrm{~mm}, 540 \mathrm{~mm}, 510 \mathrm{~mm}$, and $510 \mathrm{~mm}$, respectively. As similar to the condition of the previous simulation, it can also be noticed from the actual observation results of the underground roadway that the roadway will have the phenomena of shotcrete cracking and falling off, surrounding rock caving, and bolt plate falling off under the condition of various shape measurements.

It was observed from simulation results obtained by considering 16 orthogonal experiments that the deformation of mudstone is the largest followed by sandy mudstone, and sandstone is the most stable. Further, it was noticed from the results presented in Figure 9 that the displacement of the roadway under various conditions observed is ordered as floor heave $>$ two sides of wall $>$ roof subsidence.

The simulation for range analysis has been performed for the deformation of the roof, floor heave, and two sides of the roadway [25] $\left(R_{i}\right.$ represents the range) and presented the obtained results in Table 7 . It was observed from simulation results obtained that the influence on the stability of the surrounding rock of the tunnel is observed and ordered as lithology $>$ buried depth $>$ bolt strength $>$ shotcrete support thickness.

It can be understood based on the sensitivity analysis that two factors named the lithology (rock strength) and

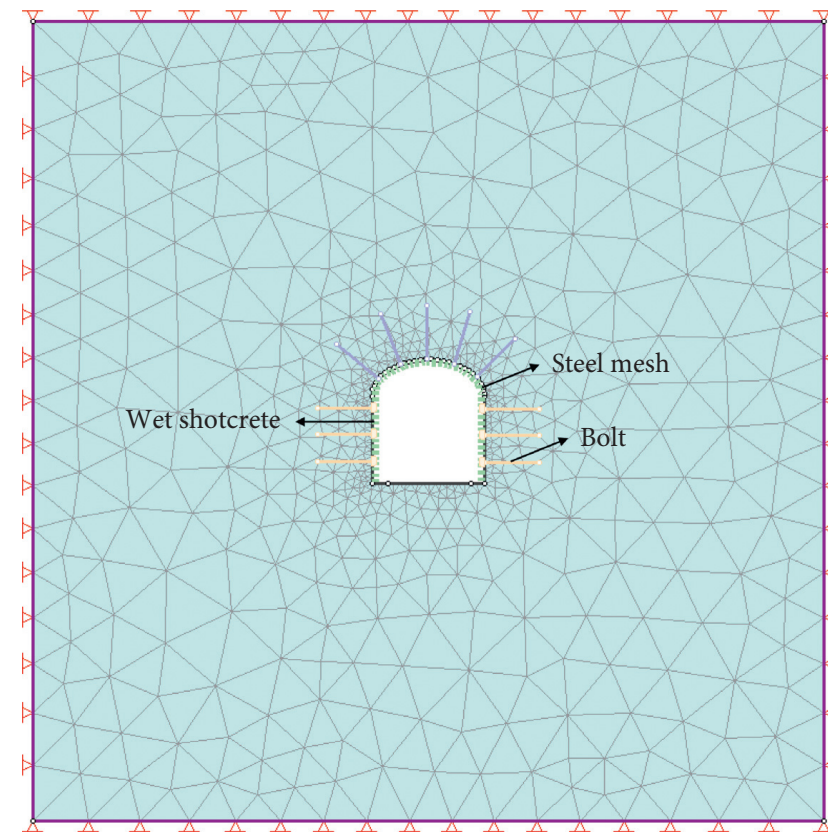

Figure 4: The numerical model.

buried depth (in situ stress) have the greatest impact on the stability of the roadway. Therefore, it was concluded that it is significant to analyze the relationship between lithology, buried depth, and the deformation of the surrounding rock of the roadway, and the study of the deformation mechanism of the roadway has been performed.

The displacement of different parts such as the roof, sidewall, and floor and the relationship between surrounding rock deformation and mining depth have been obtained by a weighted average value of $400 \mathrm{~m}-1000 \mathrm{~m}$ buried depth gradient and presented in Figure 10. It was observed that the displacement around the roadway increases with the increase of buried depth as a linear growth trend. Further, it was ordered from the results obtained with the influence of the buried depth on the surrounding displacement as floor $>$ two sides $>$ roof. It can be concluded that the larger the buried depth found is, most obviously the greater the displacement of the floor heave is compared with the sidewall and the roof. Thus, the increasing in situ stress brings about a great challenge to the support of deep soft rock roadway.

The displacement of different parts such as the roof, sidewall, and floor and the relationship between surrounding rock deformation and mining depth have been obtained by the weighted average value of four kinds of lithology and presented in Figure 11. It was observed that the 
TABLE 6: Scheme on isotropic experiment design.

\begin{tabular}{|c|c|c|c|c|}
\hline Schemes & Depth below surface $(\mathrm{m})$ & Lithology & Bolt strength $(\mathrm{KN})$ & Shotcrete thickness $(\mathrm{mm})$ \\
\hline 1 & 400 & Mudstone & 50 & 0 \\
\hline 2 & 400 & Sandy mudstone & 100 & 50 \\
\hline 3 & 400 & Argillaceous sandstone & 150 & 100 \\
\hline 4 & 400 & Sandstone & 200 & 150 \\
\hline 5 & 600 & Mudstone & 100 & 150 \\
\hline 6 & 600 & Sandy mudstone & 150 & 0 \\
\hline 7 & 600 & Argillaceous sandstone & 200 & 50 \\
\hline 8 & 600 & Sandstone & 50 & 100 \\
\hline 9 & 800 & Mudstone & 150 & 100 \\
\hline 10 & 800 & Sandy mudstone & 200 & 150 \\
\hline 11 & 800 & Argillaceous sandstone & 50 & 0 \\
\hline 12 & 800 & Sandstone & 100 & 50 \\
\hline 13 & 1000 & Mudstone & 200 & 50 \\
\hline 14 & 1000 & Sandy mudstone & 50 & 100 \\
\hline 15 & 1000 & Argillaceous sandstone & 100 & 150 \\
\hline 16 & 1000 & Sandstone & 150 & 0 \\
\hline
\end{tabular}

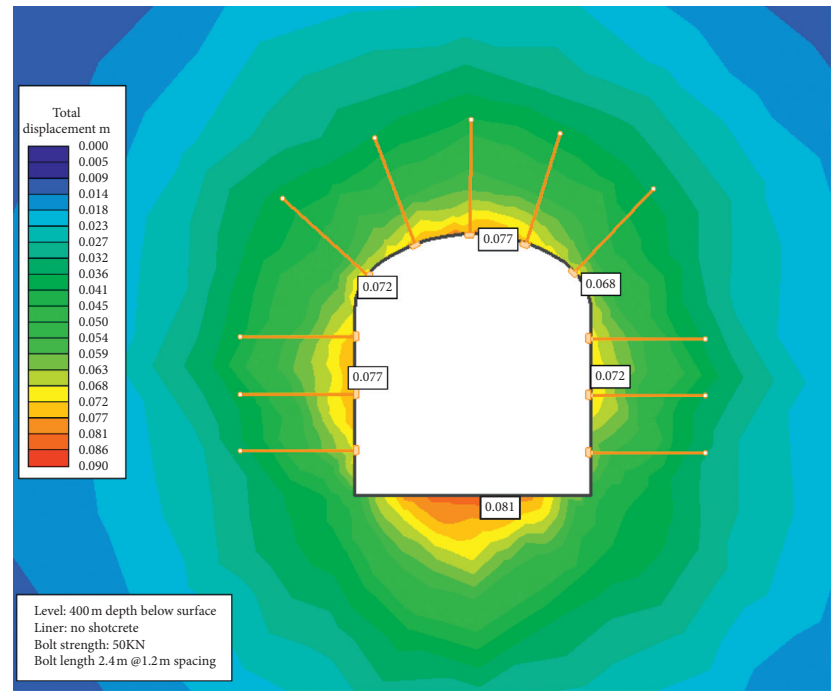

FIgURE 5: Displacement of scheme 1.

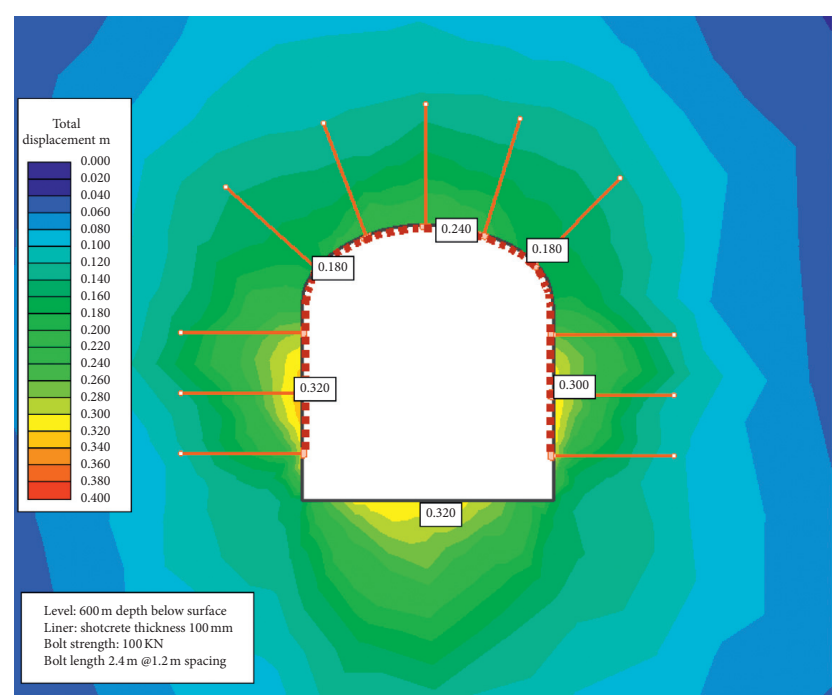

Figure 6: Displacement of scheme 5.

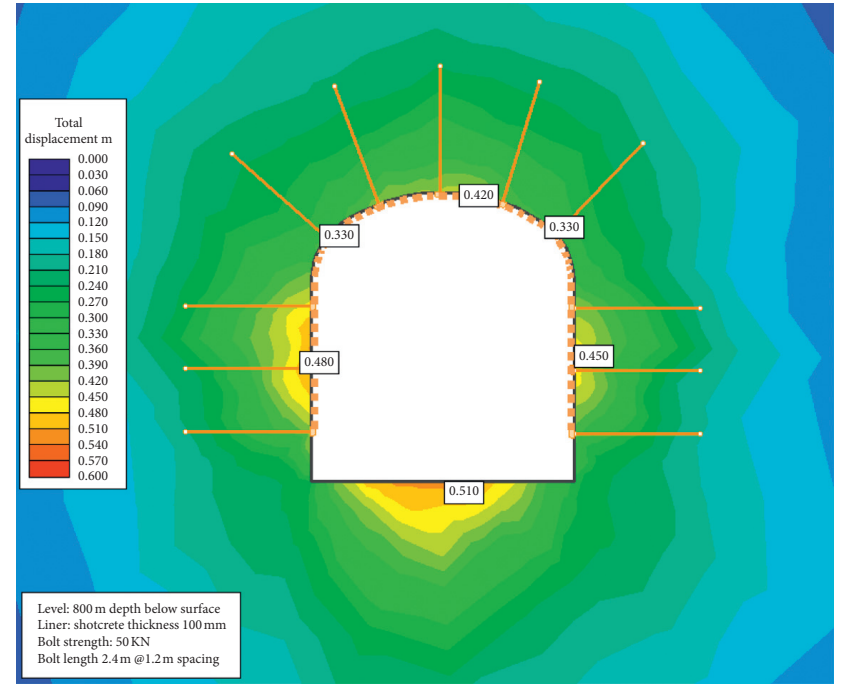

FIgURe 7: Displacement of scheme 9.

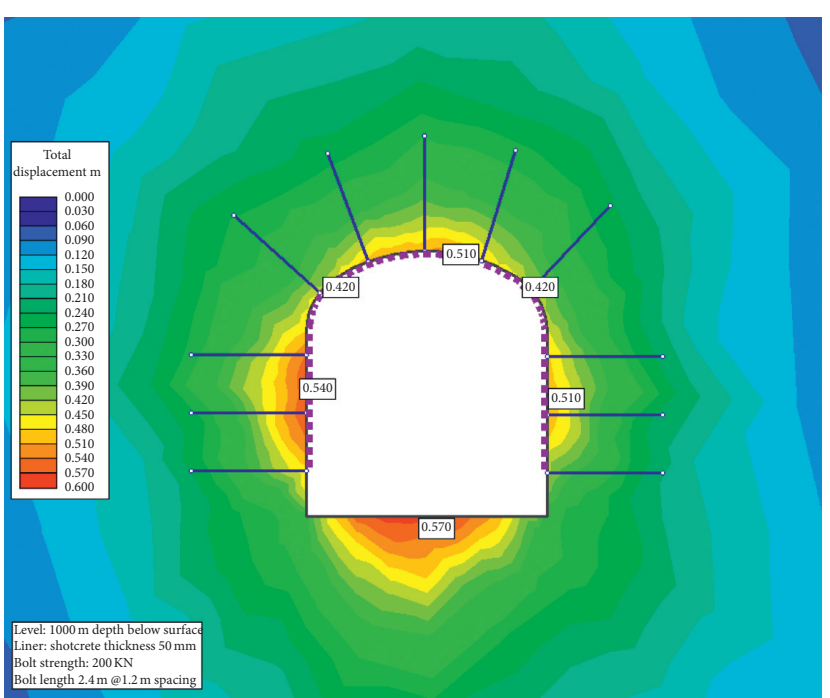

FIGURE 8: Displacement of scheme 13. 


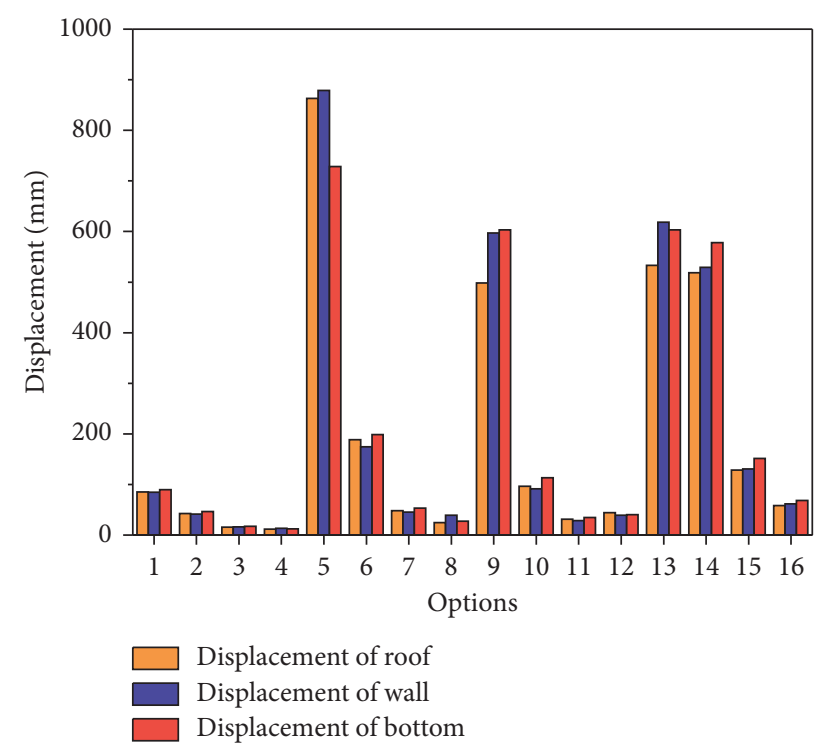

FIgURE 9: Displacement of different schemes.

TABLe 7: Sensitivity analysis.

\begin{tabular}{lcccc}
\hline Schemes & Depth below surface $(\mathrm{m})$ & Lithology & Bolt strength $(\mathrm{KN})$ & Shotcrete thickness $(\mathrm{mm})$ \\
\hline R1 & 156 & 305 & 104 & 89 \\
R2 & 161 & 346 & 119 & 98 \\
R3 & 180 & 361 & 130 & 100 \\
Average R & 166 & 337 & 118 & 95 \\
\hline
\end{tabular}

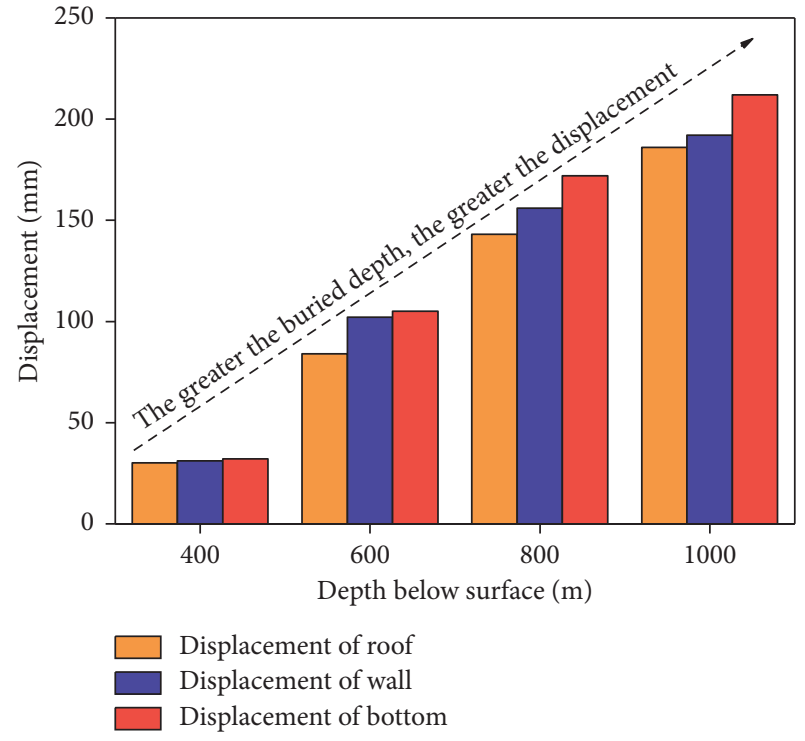

FIGURE 10: Relationship between buried depth and displacement of roadway surrounding rock.

displacement around the roadway increases with lithology from sandstone to mudstone as an exponential growth trend. It can be understood that the horizontal comparison observed is the same as that of buried depth and the order is floor heave $>$ sidewall displacement $>$ roof sedimentation with the influence of lithology on surrounding displacement.
Further, it was observed that the surrounding displacement of mudstone is 7 times higher than the other lithologies considered such as sandstone, argillaceous sandstone, and sandy mudstone. This is because low strength of mudstone softens obviously when encountering water and weakens the bearing capacity of surrounding rock seriously, resulting in its poor support.

3.3. Analysis of Surrounding Rock Deformation Mechanism. It can be understood from the analysis of the numerical test results that the deformation and failure of the deep main access roadway in Jinfeng gold mine are mainly caused by the combined action of weak mudstone strength and high in situ stress and the low support strength. The research shows that the deformation and failure of surrounding rock are staged. Firstly, the stress of surrounding rock is redistributed after excavation and the stress concentration occurs around the roadway. As a result of stress concentration, the mudstone is crushed and expanded due to exceeding the critical load. Secondly, when the mudstone reaches the softening critical load, the rheological properties of soft rock will change and leads to the "softening failure" of surrounding rock $[26,27]$ as the fracture of surrounding rock does not break to the deep, while the plastic failure range gradually increases. Finally, the surrounding rock additionally gets the significant softening effect as surrounding rock strength and other mechanical parameters are further reduced with the influence of groundwater factors. Therefore, it can be 


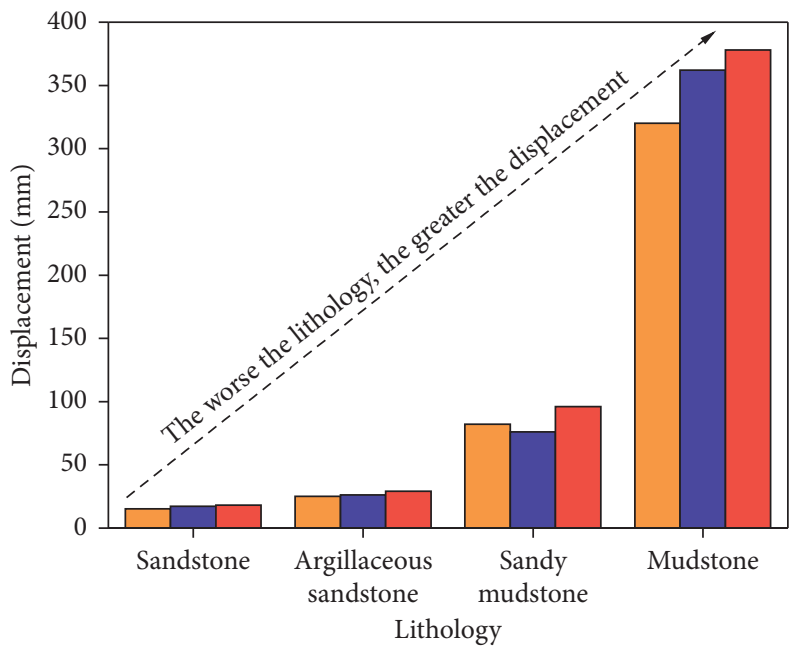

Displacement of roof

Displacement of wall

Displacement of bottom

FIGURE 11: Relationship between lithology and displacement of roadway surrounding rock.



(a)

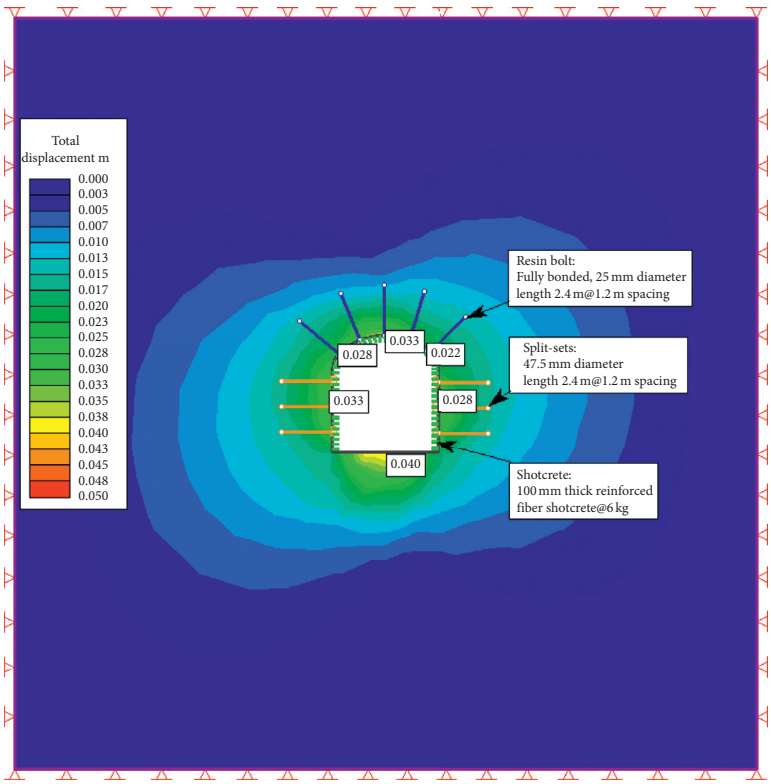

(b)

Figure 12: Continued. 


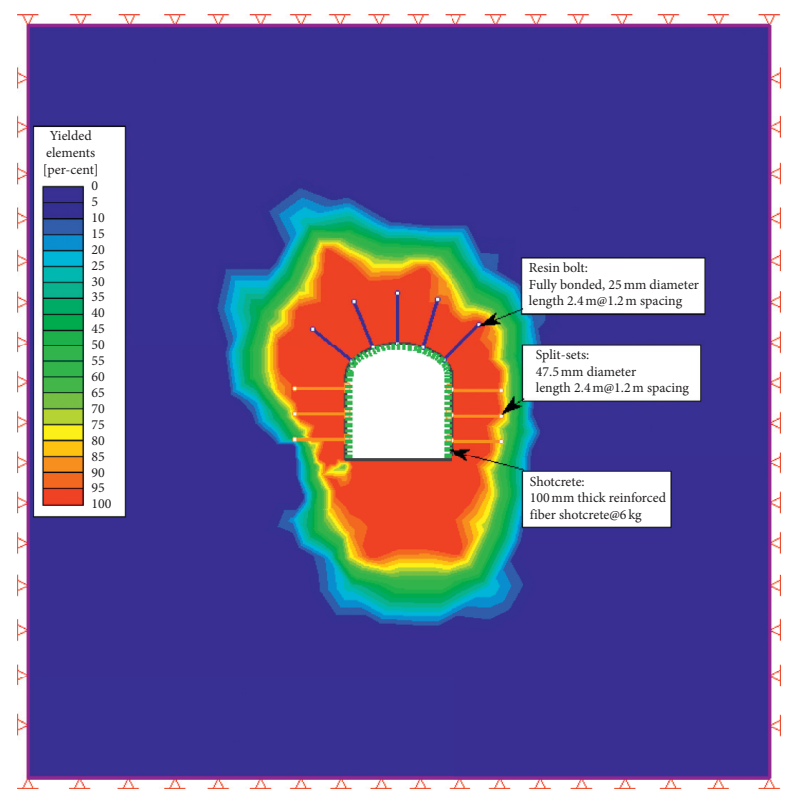

(c)

FIgURE 12: Simulation effect of the original support scheme. (a) The distribution of maximum principal stress. (b) The displacement of surrounding rock. (c) The distribution of rock mass yielding.

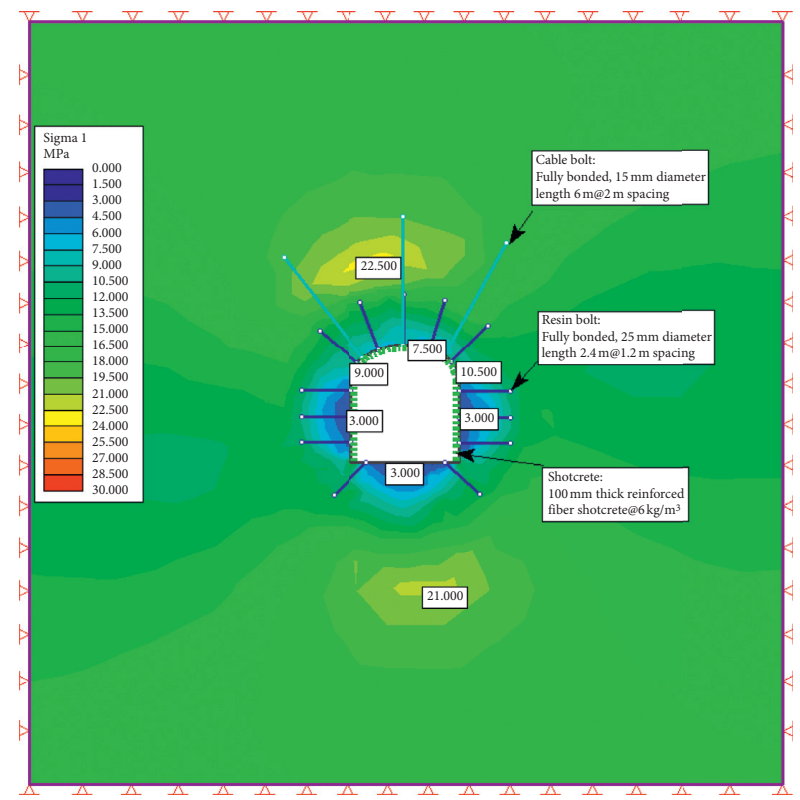

(a)

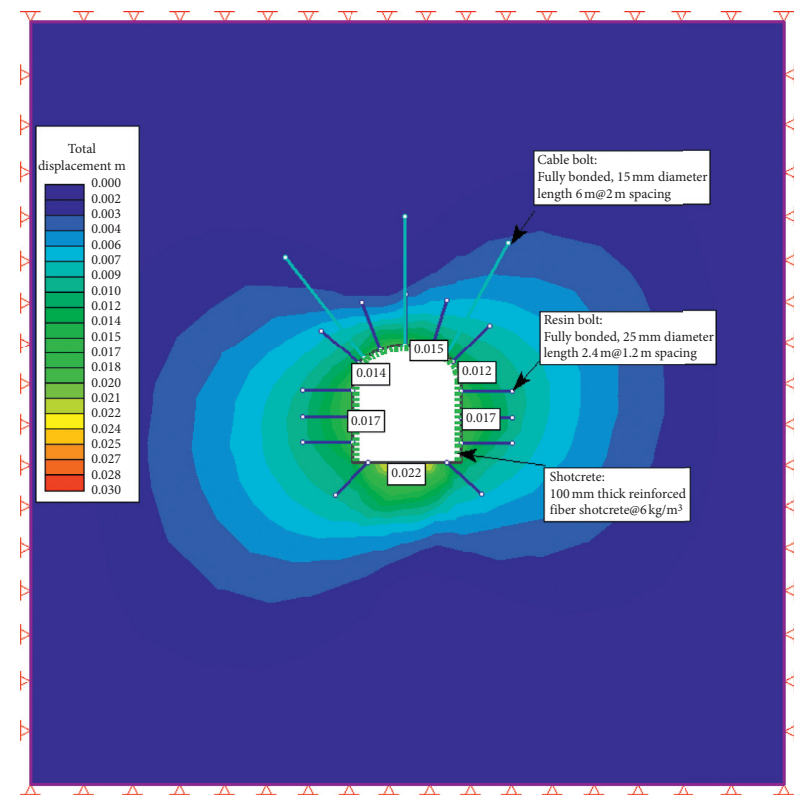

(b)

FIgURE 13: Continued. 


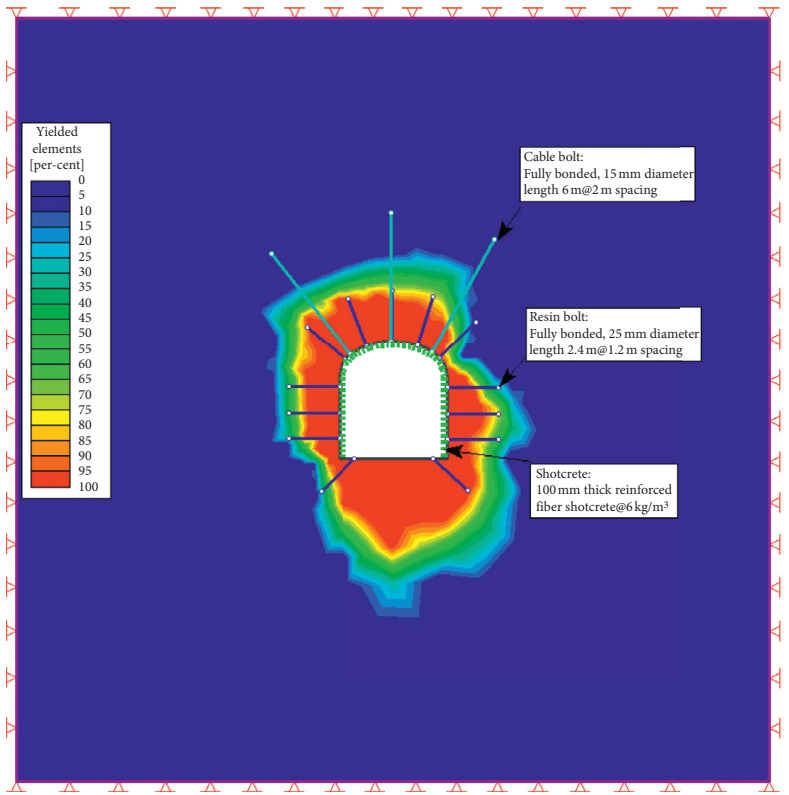

(c)

FIGURE 13: Simulation effect of the new support scheme. (a) The distribution of maximum principal stress. (b) The displacement of surrounding rock. (c) The distribution of rock mass yielding.

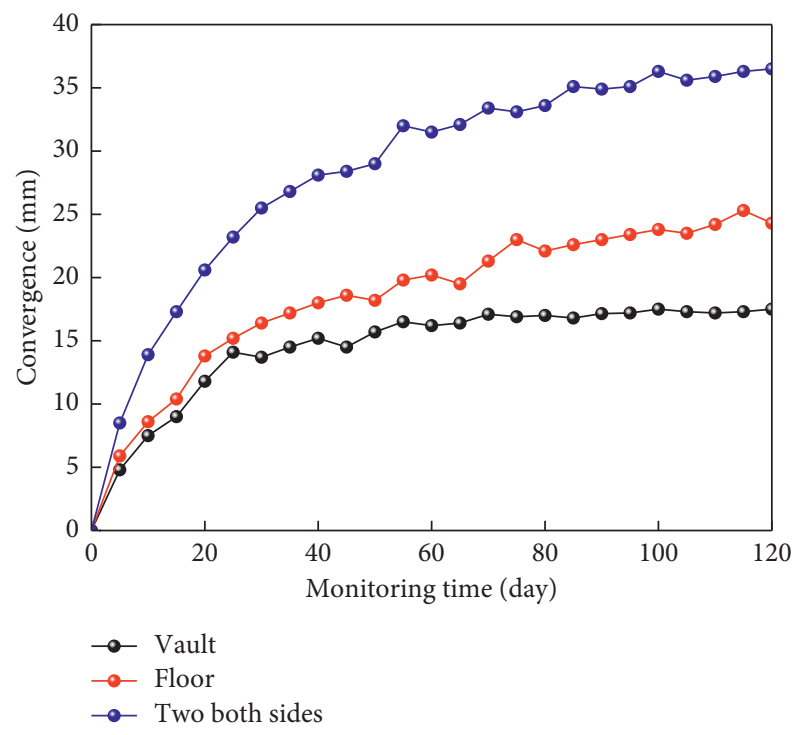

(a)

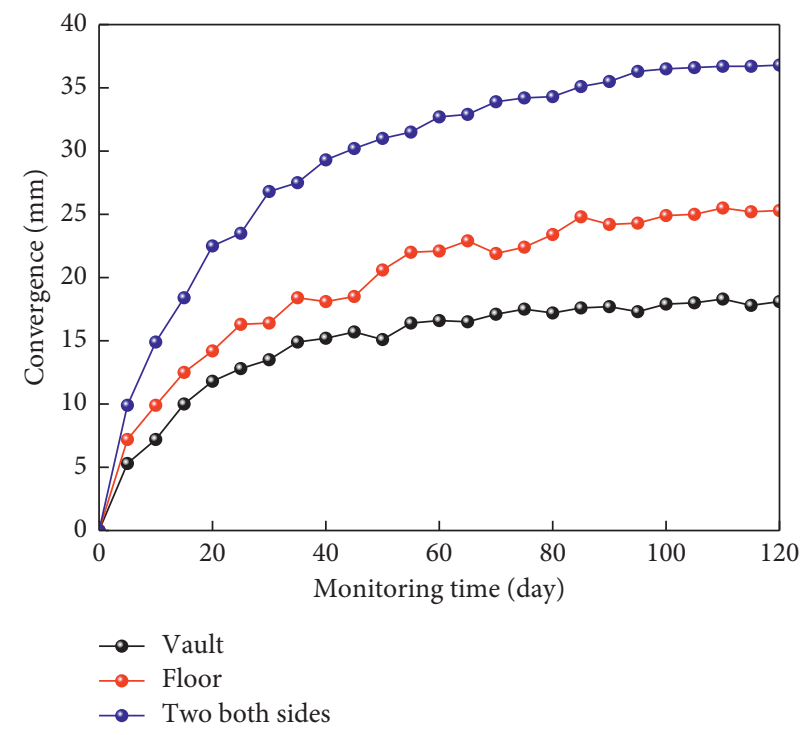

(b)

FIGURE 14: Field application monitoring results. (a) Monitoring results of station \#1. (b) Monitoring results of station \#2.

concluded that the mechanical properties of the surrounding rock in the mudstone strata of the deep roadway are to be improved to prevent the expansion of the cracks in the surrounding rock and avoid the influence of groundwater.

\section{Ground Support Strategy Research}

4.1. Ground Support Strategy. As it is known that bolting and grouting support technology provides powerful support for the control of weak broken roadway, many researchers in
China have studied in-depth research on the support mechanism and application. Zhang et al. [28] concluded from the study that grouting reinforcement of the fractured rock block support increases the uniaxial compressive strength of mudstone and siltstone and the cohesion and internal friction angle of siltstone more than $40 \%$ and $50 \%$, respectively. Liu et al. [29] conducted testing and found that the cohesion values of sandstone and mudstone structural plane after grouting are increased by 3.12 times and 22 times, respectively. Zong et al. [30] conducted compressive 
grouting reinforcement tests on fractured rock specimens and observed that the strength of fractured rock specimens after grouting was greatly improved compared with the residual strength of fractured rock mass.

It was understood from the testing that the strength of rock specimens after grouting reinforcement is $0.7 \sim 2.0$ times higher than the residual strength before grouting [31-34]. It was noticed through the field test that the grouting can fill the crack of surrounding rock in time and recement the broken rock mass together. Thus, the grouting plays an important role in preventing the crack of surrounding rock from developing to the depth and the roof water infiltration into the surrounding rock.

Therefore, the ground support strategy of this kind of surrounding rock is suggested based on the supporting concept of "resistance + yielding + resistance" of deep soft rock support developed and the application of research results obtained on "bolting and grouting" support. The supporting procedures are as follows: fiber-reinforced shotcreting in time after excavation $\longrightarrow$ bolting with split sets + meshing $\longrightarrow$ bolting with resin bolt $\longrightarrow$ fiber-reinforced shotcreting again $\longrightarrow$ cement grouting.

4.2. Parameters of Ground Support. Based on the abovestated research results of surrounding rock deformation characteristics and deformation mechanism and similar engineering analogy, the ground support proposed is put forward as follows:

(1) Resin bolt: $\Phi 25 \mathrm{~mm} @ L 2400 \mathrm{~mm}$ high-stress resin bolt installation from floor to floor. The row spacing between bolts can be $1000 \mathrm{~mm}$ by $1000 \mathrm{~mm}$. Each bolt can be anchored with $2 * 1000 \mathrm{~mm}$ resin anchoring agents and the anchoring force of each bolt can be about $200 \mathrm{kN}$.

(2) Split sets: $\Phi 47.5 \mathrm{~mm} @ L 2400 \mathrm{~mm}$ split sets installation for fixed steel mesh on the surface of the roadway. The row spacing between bolts can be $1000 \mathrm{~mm}$ by $1000 \mathrm{~mm}$. The anchoring force of each bolt can be about $60 \mathrm{kN}$.

(3) Cable bolt: $\Phi 17.8 \mathrm{~mm} @ L 6000 \mathrm{~mm}$ installation from arch to arch on the roof. The row spacing between cable bolts can be $2000 \mathrm{~mm}$ by $2000 \mathrm{~mm}$. The anchoring force of each bolt can be about $250 \mathrm{kN}$.

(4) Fiber-reinforced shotcrete: concrete strength grade can be C30, and spray thickness can be $100 \mathrm{~mm}$. The concrete mix ratio for sand:cement: water: water reducer is $1740: 440: 185: 3.6$.

(5) Steel mesh: The mesh size can be $100 \mathrm{~mm} \times 100 \mathrm{~mm}$, and the single mesh size can be $2000 \mathrm{~mm} \times 4000 \mathrm{~mm}$.

(6) Cement grouting: The loose failure depth of surrounding rock is about $1.5 \mathrm{~m}$, and, a $2 \mathrm{~m}$ long grouting bolt can be adopted for full hole perfusion, the grouting pressure can be no less than $1 \mathrm{MPa}$, and the row spacing between bolts can be $1000 \mathrm{~mm} \times 1000 \mathrm{~mm}$. The water-cement ratio can be around $0.5-0.6$. The best grouting time can be $15-20$ days after roadway excavation.

4.3. Comparison of Simulation Effect between the Proposed Scheme and the Original Scheme. A numerical simulation study was performed on the original and the proposed support schemes to verify the effectiveness of the proposed support scheme and the simulation results are presented in Figures 12 and 13 . It was concluded that the supporting effect of roadway is improved obviously after adopting the proposed support scheme of high-strength "bolting and shotcreting and grouting." It was noticed from the results that the load-carrying capacity of the surrounding rock bearing layer is significantly increased, which is significantly beneficial to the self-bearing function of the surrounding rock. Further, it was observed that the displacements of roadway roof, floor, and sidewall are reduced by $55 \%, 45 \%$, and $44 \%$, respectively, and roadway deformation is well controlled compared with the original plan. Furthermore, it was noticed that the yield range of surrounding rock is reduced, and the anchorage ends of bolt and anchor cable are in the intact surrounding rock, while the original bolt anchorage zone is in the yield failure zone of the surrounding rock, which cannot play its supporting role. Thus, it can be concluded from the simulation that the proposed support scheme is more effective than the original support considered.

\section{Engineering Application Effect}

The results obtained from this study have been applied in $90 \mathrm{~m}$ main access support engineering in Jinfeng gold mine to test the supporting effect and judge the rationality of supporting strategies and supporting parameters, the amount of roof subsidence, the cumulative movement of sidewall, and the amount of floor heave in the test section and monitored. Two measuring stations were arranged with a spacing of $25 \mathrm{~m}$ and the monitoring results are presented in Figures 14(a) and 14(b).

It was noticed from the figure that the surrounding rock deformation rate decreases significantly 15 20 days later and the surrounding rock deformation becomes stable after 60 days. It was also noticed that the convergence displacement of roof, sidewall, and floor falls to less than $1 \mathrm{~mm}$ per day and the roof maximum deformation comes around $15 \mathrm{~mm}$, while sidewall and floor heave are about $37 \mathrm{~mm}$ and $25 \mathrm{~mm}$, respectively. It can be concluded that the roadway has been in a stable state and the supporting effect is found to be good after adopting the recommended support scheme.

\section{Conclusion}

(1) In this study, the analysis and control of stability of surrounding rock in deep fractured soft rock roadway located in the underground mine of Jinfeng gold mine in Guizhou Province, China, were investigated. The surrounding rock of roadway was analyzed to characterize its deformation and failure mechanism 
through field survey, testing of rock physical and mechanical properties, in situ stress measure, analysis of mineral components of rock, and investigation of rock fragmentation degree. It can be understood from the results that the lithology of the mining area considered is primarily sandstone, sandy mudstone, mudstone, and their interbeds and the development of joint fissures of the rock mass.

(2) It can be concluded from the numerical simulation results that the surrounding rock properties (surrounding rock strength) and high in situ stress are the main factors causing the deformation and failure of deep soft rock roadway. It was understood that the physical and mechanical properties of surrounding rock and the bearing capacity of surrounding rock layer are to be improved to maintain the stability of broken soft rock roadway as high ground stress, rock fragmentation degree, and lithology (rock strength), leading to tunnel instability. Hence, a high-strength "cable bolt + fiber-reinforced shotcrete + steel mesh + split sets + resin bolt + cement grouting" combined support system was proposed to improve the effective bearing structure significantly with high integrity and bearing capacity.

(3) It was noticed from the results that the load-bearing capacity of the surrounding rock bearing layer is significantly increased, which is significantly beneficial to the self-bearing function of the surrounding rock. Further, it was observed that the displacements of roadway roof, floor, and sidewall are reduced by $55 \%, 45 \%$, and $44 \%$, respectively, and roadway deformation is well controlled compared with the original plan. Furthermore, it was noticed that the yield range of surrounding rock is obviously reduced, and the anchorage ends of bolt and anchor cable are in the intact surrounding rock, while the original bolt anchorage zone is in the yield failure zone of surrounding rock, which cannot play its supporting role. Thus, it can be concluded from the simulation that the proposed support scheme is more effective than the original support considered.

\section{Data Availability}

The data used to support the findings of this study are available from the first author upon request.

\section{Conflicts of Interest}

The authors declare that they have no conflicts of interest.

\section{Acknowledgments}

This study was supported by the National Natural Science Foundation of China (51964007, 51774101, and 41962008), the High Level Innovative Talents Training Project in Guizhou Province (Project no. 2016-4011), and the Guizhou
Mining Power Disaster Early Warning and Control Technology Innovation Team Fund (Project no. 2019-5619).

\section{References}

[1] M. C. He, "Comception "system and evaluation indexes for deep engineering," Chinese Journal of Rock Mechanics and Engineering, vol. 16, pp. 2854-2858, 2005.

[2] S. M. Chen, A. X. Wu, S. Y. Wang et al., "Deformation mechanism and repair control technology of soft surrounding rock roadway," Journal of China University of Mining \& Technology, vol. 47, no. 4, pp. 830-837, 2018.

[3] F. L. He and G. C. Zhang, "Analysis and control of stability of the fractured soft rock surrounding a deep roadway," Rock and Soil Mechanics, vol. 36, no. 5, pp. 1397-1406, 2015.

[4] H. J. Zhang, H. Y. Li, S. C. Li et al., "Deformation mechanism of surrounding rock and support technology in deep soft rock roadway," Journal of Mining \& Safety Engineering, vol. 32, no. 6, pp. 955-962, 2015.

[5] D. H. Chen and X. Z. Hua, "The deformation law of the surrounding rock in deep mining roadways under the influence of multi-factors and the control countermeasures," Journal of Mining \& Safety Engineering, vol. 34, no. 4, pp. 760-768, 2017.

[6] J. Liu, M. He, Y. Wang et al., "Stability analysis and monitoring method for the key block structure of the basic roof of noncoal pillar mining with automatically formed gob-side entry," Advances in Civil Engineering, vol. 2019, Article ID 5347683, 14 pages, 2019.

[7] Z. G. Tao, J. D. Cao, L. Yang et al., "Study on deformation mechanism and support measures of soft surrounding rock in muzhailing deep tunnel," Advances in Civil Engineering, vol. 2020, Article ID 9367916, 14 pages, 2020.

[8] R. S. Yang, Y. L. Li, D. M. Guo et al., "Deformation reasons and support technology of deep and high-stress soft rock roadway," Journal of Mining \& Safety Engineering, vol. 34, no. 6, pp. 1035-1041, 2017.

[9] W. P. Huang, C. Li, W. B. Xing et al., "Asymmetric deformation mechanism and control technology of roadway with depth over 1000 meters under rheological state," Journal of Mining \& Safety Engineering, vol. 35, no. 3, pp. 481-488+495, 2018.

[10] Q. B. Meng, W. H. Qian, J. Li et al., "Stability control technology of roadway surrounding rock in soft ore body and its application," Journal of Mining \& Safety Engineering, vol. 36, no. 5, pp. 906-915, 2019.

[11] L. H. Sun, B. S. Yang, C. D. Sun et al., "Experimental research on mechanism and controlling of floor heave in deep soft rock roadway," Journal of Mining \& Safety Engineering, vol. 34, no. 2, pp. 235-242, 2017.

[12] M. C. He, "Progress and challenges of soft rock engineering in depth," Journal of China Coal Society, vol. 39, no. 8, pp. 1409-1417, 2014.

[13] G. C. Zhang and F. L. He, "Deformation failure mechanism of high stress deep soft roadway and its control," Journal of Mining \& Safety Engineering, vol. 32, no. 4, pp. 571-577, 2015.

[14] W. J. Wang, C. Yuan, W. J. Yu et al., "Stability control method of surrounding rock in deep roadway with large deformation," Journal of China Coal Society, vol. 41, no. 12, pp. 2921-2931, 2016.

[15] B. Rahimi, M. Sharifzadeh, and X. T. Feng, "“Ground behavior analyses, support system design and construction strategies in deep hard rock mining-Justified in Western Australian's 
mines," Journal of Rock Mechanics and Geotechnical Engineering, vol. 1, no. 12, pp. 1-20, 2020.

[16] G. Li, F. S. Ma, J. Guo et al., "Study on deformation failure mechanism and support technology of deep soft rock roadway," Engineering Geology, vol. 105262, no. 264, pp. 1-15, 2020.

[17] Q.-Y. Zhang, Y. Zhang, K. Duan, C.-C. Liu, Y.-S. Miao, and $\mathrm{D}$. $\mathrm{Wu}$, "Large-scale geo-mechanical model tests for the stability assessment of deep underground complex under true-triaxial stress," Tunnelling and Underground Space Technology, vol. 83, no. 264, pp. 577-591, 2019.

[18] H. P. Xie, "Research framework and anticipated results of deep rock mechanics and mining theory," Advanced Engineering Sciences, vol. 49, no. 2, pp. 1-16, 2017.

[19] J. H. Yang, J. H. Dai, C. Yao et al., "Estimation of rock mass properties in excavation damage zones of rock slopes based on the Hoek-Brown criterion and acoustic testing," International Journal of Rock Mechanics and Mining Sciences, vol. 126, Article ID 104192, 2020.

[20] A. Li, N. Xu, F. Dai, G. Gu, Z. Hu, and Y. Liu, "Stability analysis and failure mechanism of the steeply inclined bedded rock masses surrounding a large underground opening," Tunnelling and Underground Space Technology, vol. 77, pp. 45-58, 2018.

[21] X. Y. Hu, C. He, X. H. Lai et al., "Study on the interaction between squeezing ground and yielding supports with different yielding materials," Tunnelling and Underground Space Technology, vol. 97, p. 19, Article ID 103242, 2020.

[22] S. Song, X. Feng, C. Liao, D. Cai, Z. Liu, and Y. Yang, "Measures for controlling large deformations of underground caverns under high in-situ stress condition - a case study of Jinping I hydropower station," Journal of Rock Mechanics and Geotechnical Engineering, vol. 8, no. 5, pp. 605-618, 2016.

[23] F. T. Dong, H. W. Song, Z. H. Guo et al., "Support theory of roadway surrounding rock loose ring," Journal of China Coal Society, vol. 19, pp. 22-32, 1994.

[24] Y. Li, X. Tang, S. Yang, and J. Chen, "Evolution of the broken rock zone in the mixed ground tunnel based on the DSCM," Tunnelling and Underground Space Technology, vol. 84, pp. 248-258, 2019.

[25] S. H. Yin, A. X. Wu, X. W. Li et al., "Orthogonal polar difference analysis for sensitivity of the factors influencing the ore pillar stability," Journal of China Coal Society, vol. 37, pp. 48-52, 2012.

[26] D. F. Malan, "Manuel rocha medal recipient simulating the time-dependent behaviour of excavations in hard rock," Rock Mechanics And Rock Engineering, vol. 35, no. 4, pp. 225-254, 2002.

[27] D. F. Malan and F. R. P. Basson, "Ultra-deep mining: the increase potential for squeezing conditions," Journal of the Southern African Institute of Mining and Metallurgy, vol. 98, pp. 353-363, 1998.

[28] N. Zhang, C. J. Hou, Q. M. Chen et al., "Mechanical properties of broken rock after grouting reinforcement," Rock and Soil Mechanics, vol. 19, no. 3, pp. 50-53, 1998.

[29] C. W. Liu and S. L. Lu, "Reinforcement effect of cement grouting on engineering rock mass," Journal of China University of Mining \& Technology, vol. 29, no. 5, pp. 454-458, 2000.

[30] Y. J. Zong, L. J. Han, and G. L. Han, "Mechanical characteristics of confined grouting reinforcement for cracked rock mass," Journal of Mining \& Safety Engineering, vol. 30, no. 4, pp. 483-488, 2013.
[31] H. P. Wang, Y. F. Gao, and S. C. Li, "Uniaxial experiment study on mechanical properties of reinforced broken rocks pre-and-post grouting," Chinese Journal of Underground Space and Engineering, vol. 3, no. 1, pp. 27-39, 2007.

[32] W. J. Yu, G. S. Wu, B. Pan et al., "Experimental investigation of the mechanical properties of sandstone-coal-bolt specimens with different angles under conventional triaxial compression," International Journal of Geomechanics, vol. 21, no. 1, pp. 1-12, 2021.

[33] W. Yu, B. Pan, F. Zhang, S. Yao, and F. Liu, "Deformation characteristics and determination of optimum supporting time of alteration rock mass in deep mine," KSCE Journal of Civil Engineering, vol. 23, no. 11, pp. 4921-4932, 2019.

[34] W. Yu and K. Li, "Deformation mechanism and control technology of surrounding rock in the deep-buried large-span chamber," Geofluids, vol. 2020, no. 5, pp. 1-22, Article ID 8881319, 2020. 